U.Ü. FEN-EDEBIYAT FAKÜLTESI SOSYAL BILIIMLER DERGISI

Yıl: 19, Sayı: 30, 2016/1

\title{
THE CONDITION OF THE CULTURAL AND HISTORICAL RESOURCES OF THE PAVLODAR REGION
}

\author{
Altynbek ZHAKUPOV ${ }^{1}$ \\ Emin ATASOY ${ }^{2}$ \\ Alaattin KIZILÇAOĞLU \\ Jan A. WENDT ${ }^{4}$
}

\section{ABSTRACT}

The Pavlodar region is located in the northeast of Kazakhstan. The most part of the territory of the Pavlodar region is in limits of the South of the West Siberian Plain on average a watercourse of the river Irtysh, and occupies the space of 127,5 thousand $\mathrm{km}^{2}$. In the north the area borders with the Russian Federation (Omsk region), in the south - with the Karaganda region, in the east - with East Kazakhstan, in the West - with Akmolinskaya and North Kazakhstan regions.

Total, there are about 1000 archaeological monuments in the area, most of which, 705 are included in "The arch of monuments of the Pavlodar region", but the potential of their further identification isn't exhausted yet. From 12 districts of the region, the greatest numbers of monuments of archeology are three largest districts, Bayanaul, Mayskiy and Ekibastuz have, and then follow Pavlodar, Lebyazhinskiy, Shcherbaktinskiy and other districts. The article discusses the situation in the region at the moment as the main tourist cluster component.

Key Words: Tourist, historical-cultural tourism attractiveness, archaeological tourism attractiveness.

1 Eurasian National University named after L.N. Gumilyov 01008, Astana city, Kazakhstan.

2 Uludag University, Faculty of Education, Department of Elementary Education, Gorukle Campus, Bursa, Turkey

3 Department of Social Sciences, Faculty of Necatibey Education, University of Balıkesir, Balıkesir, Turkey

4 Institute of Geography Gdansk Poland, Gdansk University, Poland. 


\section{ÖZET}

\section{Pavlodar Vilayetinin Kültürel ve Tarihsel Turizm Potansiyeli}

Bu çalışmada Pavlodar vilayetinin (oblast veya il) kültürel, arkeolojik ve tarihi çekiciliklerin bölgesel turizm potansiyelinin bir parçası olarak irdelenmiştir. Vilayet sınırları içinde yer alan Ekibastuz ve Bayanaul arkeolojik parkları bölgedeki kültür turizmin en zengin kaynaklarını oluşturmaktadırlar. Çalışmada bölgesel turizmin olanaklarl ve potansiyeli yaz çalışma kampları ve farkl gezi etkinlikleriyle açıklanmıştır. $127500 \mathrm{~km}^{2}$ 'lik alana sahip olan Pavlodar oblastı Kazakistan'ın kuzeydoğusunda ülkenin en büyük akarsuyu olan Irtış nehri klylsında yer almaktadır. Pavlodar oblastı kuzeyden Rusya'ya bağılı olan Omsk ve Novosibirsk oblastlarl, güneyden Kazaraganda oblastı ve Doğu-Kazakistan oblastl, doğudan Altay Cumhuriyeti ve batıdan da Akmolinsk ve Kuzey- Kazakistan oblastı ile çevrilidir. Oblast sinırları içinde toplam 1000 arkeolojik turizm çekiciliği yer almaktadır, bunlardan 705' $i$ Pavlodat vilayetinin antlar listesinde yer almaktadırlar, fakat turizm potansiyelleri tam olarak ortaya çıkartılmamıştır. Vilayet sinırları içindeki 12 ilçeden en fazla arkeolojik turizm çekiciliğine sahip ilçelerin başıında Ekibastuz, Mayski ve Bayanaul gelmektedirler. Daha sonra stralamada Pavlodarskiy, Lebyajinskiy ve Şterbaktinskiy ilçeleri gelmektedirler.

Anahtar Kelimeler: Turist, tarihsel-kültürel turizm çekicilikleri, arkeolojik turizm çekicilikleri.

\section{INTRODUCTION}

The Pavlodar region thanks to the unique nature, a geographical position, history possesses rather high potential for tourism development; however, tourist objects are still little-known to the international community and domestic market.

The most part of tourist trips to the Pavlodar region is made by a share of internal tourism, it is very favorable factor for development of domestic tourism. The stream of outbound tourism is exceeded by indicators of entrance tourism, and so far it isn't balanced.

Total, there are about 1000 archaeological monuments in the area, most of which, 705 are included in "The arch of monuments of the Pavlodar region", but the potential of their further identification isn't exhausted yet. Considering scales of districts, number of their population, natural, cultural and historical and tourist and recreational potential, the main loading of use of archaeological monuments in tourist branch is also the share of areas Bayanaul, Ekibastuz and Pavlodar. 
The main archaeological collections are collected in the Regional local history museum and the Museum of archeology of PSU named after S. Toraygyrov where the exposition built in chronological sequence and telling about development of material and spiritual culture of the ancient and medieval population of Priirtyshje is created.

Having studied possibilities of use of archaeological monuments of the region in development of internal tourism, the working group allocates two main regional directions of their use - Bayanaul and Ekibastuz. Drawing up special routes with departure, both from the cities of Pavlodar, Ekibastuz and Aksu, and Bayanaul, from where will be directly formed the main center of the archaeological sites in the development of tourist-excursion area (Aryn et al. 2003a).

Independent center of tourist-excursion will be Ekibastuz district, which also has huge historical and cultural potential and cultural and educational organizations such as the historical museum.

The third direction can be developed near Akshamansky Mountains in the Mayskiy district, but this region is still poorly studied and is characterized by the undeveloped infrastructure which isn't allowing to speak so far about specific projects on development of tourism in this area. About use of archaeological monuments in development of tourism in other regions of area also so far there are no bases to speak, but prospects are.

\section{RESULTS AND DISCUSSION}

Monuments of the Bayanaul district. Bayanaul district has more than 200 monuments of archeology most of which can be used as tourist objects. However in Bayanaul the large regional center and the center of tourism of the Pavlodar region, except for the museum named after K.I. Satpayev, no cultural and educational institutions with which acquaintance to sights and history of edge could begin. Though here it would be possible to create the museum of the nature of Bayanaul, such as, there is a museum of the nature in Borovoe, and also to create the local history museum which has in almost every district of the region, except Bayanaul that is definitely unacceptable for further social development of the regional center (Aryn et al. 2003b).

The most interesting archaeological sites are located around the Bayanaul mountain forest for use in the tourism industry which is necessary to conduct archaeological research on them, restore and museumification, involves the creation of special infrastructure to ensure their preservation and maintenance. Most of these objects can be included in a special tourist route around the Bayanaul Mountains under the conditional name 
"Bayanaul's Antiquities" or "Golden Ring of Bayanaul". Originally it can include the following objects:

\begin{tabular}{|c|l|}
\hline 1 & Kurgan of the early Iron Age of a burial ground of "Sabyndykol" \\
\hline 2 & $\begin{array}{l}\text { Ritual complex of barrows with "moustaches" and stone sculptures early iron and the Middle } \\
\text { Ages Karazhar. }\end{array}$ \\
\hline 3 & Stone sculptures of "Birzhankol". \\
\hline 4 & Cave "Konyr Auliye". \\
\hline 5 & Rock paintings on the northwest coast of Zhasybay. \\
\hline 6 & Ritual complex of an early sak era with deer stones on the bank of the lake Toraygyr. \\
\hline 7 & Petroglyphs in the natural boundary of "Bestobe". \\
\hline
\end{tabular}

The remarkable monuments such as the cultural and historical sites and why they are offered for museumification, tourists and development of archaeological and tourist-excursion cluster and Bayanaul district of the Pavlodar region as a whole. Let us consider each of them separately.

This stage of ancient history of our edge isn't studied yet therefore it would be very important to investigate this monument and then to add to the category of museum objects as it has great scientific and cultural and historical value for studying of spiritual culture of tribes of an era of bronze and early nomads of Kazakhstan.

Barrow of the early Iron Age of a burial ground of "Sabyndykol". The monument is located $5 \mathrm{~km}$ to the South from the settlement of Bayanaul, $1 \mathrm{~km}$ to the South from a recreation area of Ekibastuz SDPP (State District Power Plant)-1, on the right coast of the stream the Fish key flowing from the southwest part into the lake Sabyndykol, $300 \mathrm{~m}$ from the highway to Karaganda, parallel to the road departing from the highway in the former pioneer camp Fakel.

It consists of 24 stone fences bronze epoch developed, constructed of granite slabs on the edge dug into the ground, and 4 stone mounds. The monument was badly damaged during the construction of roads, part of the fence was destroyed.

The monument has great scientific and cultural and historical value as a source of material and spiritual culture of tribes of an era of bronze and the early Iron Age of Northeast Saryarka. As barrows are already investigated by archeologists, carrying out their restoration and a museumification is necessary.

Ritual complex of barrows with "moustaches" and stone sculptures of the early Iron and the Middle Ages Karazhar. The monument is located $1,5 \mathrm{~km}$ from the highway to Karaganda in the picturesque natural boundary between two streams, on a small hill behind the village of the same name. Consists also groups of cult constructions of the early and medieval nomads 
presented by very difficult designs of two barrows with "moustaches" and a medieval sculpture located consistently in the southeast direction.

The monument has great scientific and cultural and historical value as a source for studying of spiritual culture of early and medieval nomads of Northeast Saryarka, therefore needs special studying, reconstruction and a museumification as one of the most interesting and well remained objects.

Stone sculptures of "Birzhankol". Stone sculptures of Birzhankol are located $3 \mathrm{~km}$ to the southwest from the village of Birzhankol on a gentle slope of the mountain and at its bottom on the bank of a stream at a country road. Monuments represent two cult objects of medieval nomads. The monument is considerably destroyed and grew with trees, needs studying, cleaning of vegetation, restoration and a museumification.

The monument represents the man's image of Turkic time established at a small fencing from stone plates, located $500 \mathrm{~m}$ to the North from sculptures of Birzhankol. It also needs studying, restoration and a museumification (Artykbaev and Bayanaula 2001).

Konyrauliye's cave. The cave of "Konyrauliye" which was once a habitat of ancient hunters of the Neolithic era and bronze, now is a pilgrimage place. Possibly, and in the ancient time it could play a role of a cult monument, and not just a shelter for hunters and cattle-farmers. The cave $12 \mathrm{~km}$ is located to the West from the village of Bayanaul within the territory of Bayanaul State National Natural Park in the picturesque gorge in the southwest from the natural boundary Zhambak. Represents corridorshaped deepening in the rock about $30 \mathrm{~m}$ long up to 2,5 - $3 \mathrm{~m}$ wide consisting of two halls with high ceilings, focused by an exit to the west (Pic. 1).
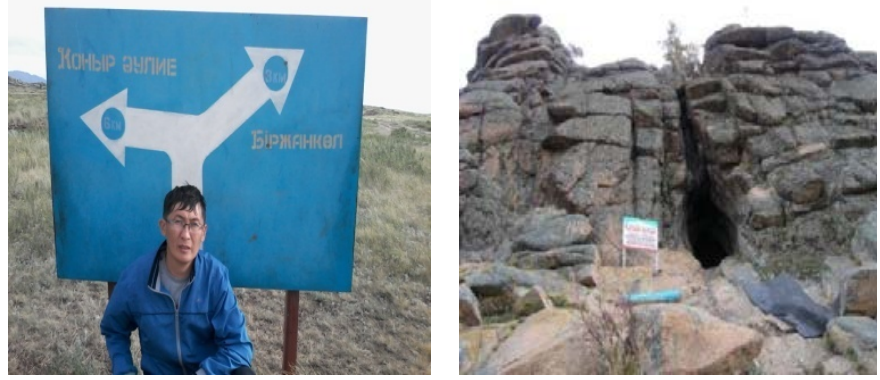

Pic. 1. General view to the Cave Konyrauliye

From the cave to a look of tourists the beautiful view of the foothill valley and the stretching steppe distances opens. At the foot of the mountain on which there is the cave, the settlement of an era of bronze is found. It is 
dated for the right coast of the stream passing near the mountain. The monument is connected with spiritual culture of the ancient population of Northeast Saryarka. Many legends and the stories are also connected with the cave (Zhakupov 2014).

Rock paintings on the northwest coast of Zhasybay. Rock paintings of the northwest coast of the lake Zhasybay are located 8,5 km to the northwest from the village of Bayanaul, $100 \mathrm{~m}$ to the North from the coast of the lake, nearby the highway on Toraygyr. Drawings are placed in niches of East side of the high rock. The monument is opened in 1972 by the Pavlodar local historians G. Y. Korobkin and A.F. Aleynik.

Rock paintings are executed by red ochre on walls and ceiling part of canopies and in niches. Images occupy some sites from different sides of the rock: northern part - three sites, southern - 4 and two small niches on which about 30 figures are looked through, about 12 from them it is possible to define as anthropomorphous, other are images of some structures, fences, signs, perhaps birds.

The monument is a cult place of ancient inhabitants of Bayanaul, has great scientific and cultural and historical value as a source on primitive art, archeology and history of spiritual culture of ancient tribes of Northeast Saryarka. Uniqueness of this object assumes obligatory for its museumification for further use in the scientific and tourist purposes.

\section{Ritual complex of an early Sak era with Deer stones on the bank of the lake Toraygyr - Toraygyr VI.}

The monument is located in a recreation area of the east coast of the lake Toraygyr. Consists of 21 stones and earth embankments with a diameter from 2 to $18 \mathrm{~m}, 0,2$ - 0,6 m high, including a barrow with moustaches and steles with the image of deer in Scythian-sak animal style - "The Deer stone", and also steles with images of rings and figures of goats.

The monument represents group of cult and funeral constructions of early nomads, has great scientific and cultural and historical value as a source for studying of a funeral ceremony and cult constructions of early nomads of the Central Kazakhstan. The object strongly suffered from anthropogenous influence and needs special studying, reconstruction and a museumification. It is located $16 \mathrm{~km}$ to the West from the highway Pavlodar - Bayanaul, in $3 \mathrm{~km}$ to the East of the village of Toraygyr.

Petroglyphs in Bestobe's natural boundary. The monument is located in $70 \mathrm{~km}$ to the southwest from Bayanaul, 5-7 km from Bayanaul highway Kara-tomar, $5 \mathrm{~km}$ to the East from the village of Muryntal, on the left coast of a stream. Petroglyphs are executed in style of "Deer stones", belong to the early Iron Age. It is the only monument of this kind in the territory of the Pavlodar region, and one of the few in the territory of 
Kazakhstan. On a hill slope, the bottom of rocky exposures, opposite to the plane, has a ring-shaped altar put from stones.

The monument has great scientific and cultural and historical value as the object reflecting cult and ideological representations of cattle-farmers of an era of the early Iron Age of Northeast Saryarka therefore needs special studying and a museumification as one of the most interesting and well remained objects. On coast of a stream, also the set of various monuments of archeology is revealed, these are burial grounds of an era of bronze and early iron, stone sculptures of medieval nomads which together with Petroglyphs make uniform, a complex and also can be used further as the visited objects (Yensebayev 2001).

Monuments of the Ekibastuz district. The Ekibastuz district has more than 300 monuments of archeology, most of them can be used as tourist objects. In a complex the local history museum in which the archaeological exposition is presented also works with them.

The most interesting archaeological monuments are located round Ekibastuz and in valleys of the rivers of Olentiy and Shyderty, which can be used as objects in tourist branch only after carrying out archaeological researches, restoration and a museumification, and also creation of special infrastructure of ensuring their safety and service. Many of these objects can be included in a special tourist route round Ekibastuz under the conditional name "Antiquities of Ekibastuz", to valleys of the rivers of Olentiy and Shyderty, separate monuments such, as The writings of Olentinskiy, Rock paintings of the Ak-Bidaik tract and some other single monuments. Initially, it may include the following items:

\begin{tabular}{|c|l|}
\hline 1 & Petroglyphs "The writings of Olentinskiy" \\
\hline 2 & Rock paintings of the Ak-Bidaik tract \\
\hline 3 & Settlement of an era of bronze Maykain \\
\hline 4 & Early man site of the Stone Age Angrensor 2 and settlement of an era of bronze Angrensor 1 \\
\hline 5 & Monuments of the Shidertinskiy archaeological complex \\
\hline 6 & Kurgan group Karasor 1 \\
\hline
\end{tabular}

Petroglyphs "The writings of Olentinskiy".The monument is located $100 \mathrm{~km}$ to the northwest from Ekibastuz, the asphalt road to object only to the village Totruy (40 km), further a dirt road and the grader of very bad quality. Tai (the former farm "Olentinskiy") is dated for a slope of the cool river bank of Olentiy, near an old Kazakh cemetery $5 \mathrm{~km}$ to the southwest of the village.

The monument is a cult place of ancient cattle-farmers of an era of an eneolit, bronze and early iron centuries. As one of the few and the most 
northern monument of an ancient petroglyphic art, and a source on spiritual culture of ancient tribes of Northeast Saryarka has unique cultural and historical and scientific value.

Rock paintings of the Ak-Bidaik tract are located $3 \mathrm{~km}$ to the southeast from station Maykain and $5 \mathrm{~km}$ to the South from $100 \mathrm{~km}$ of a highway Ekibastuz - Pavlodar on the northwest suburb of the natural boundary of the same name. Such provision of a monument makes it available for visit and creation of conditions for the organization of tourist service.

The monument underwent strong destruction therefore many drawings are lost. However that remained, is magnificent reflection of the reality embodied in artistic images, at least, of three-four stages of primitive culture of the northeast suburb of Saryarka: Neolithic, eneolit, era of bronze and early Iron Age. It isn't excluded that some drawings can belong and to later eras, the monuments of various eras close to Petroglyphs testify to it.

Settlement of an era of bronze of Maykain. The settlement of Maykain, is located 2,5 km to the southwest from the station of the same name. The monument is dated for a northeast slope of a small hill. Consists of several housing hollows of an oval form with a diameter from 20 to $40 \mathrm{~m}$ and the remains of the land designs put from stones.

The monument is the stationary settlement of ancient cattle-farmers. Has scientific and cultural and historical value as a source on material culture of cattle breeding tribes of Northeast Saryarka (Akhmetov and Nurpeisov 2003).

\section{Early man site of the Stone Age Angrensor 2 and settlement of} an era of bronze Angrensor 1. Surroundings of the lake Angrensor which is in $20 \mathrm{~km}$ to the southeast from Ekibastuz, and also the whole complex of the archaeological monuments located near it, can become one more object of visit of tourists. But first of all it is the early man site of the Stone Age Angrensor 2 and settlement of an era of bronze Angrensor 1, being the most significant objects near the lake Angrensor, located from East side from the highway Ekibastuz - Maykain. Early man site of an era of paleolith and eneolit of Angrensor 2 is a habitat and a workshop on production of stone tools of ancient hunters and cattle-farmers. Is one of the few stratified paleolith era monuments and an eneolit era, has great scientific and cultural and historical value as a source for studying of material culture of ancient hunters. The monument is damaged as a result of farming, is in need of conservation and research activities. At the same creek, downstream, is a Bronze Age settlement, consisting of several housing cavities with the remains of stone structures. 
Monuments of the Shidertinskiy archaeological complex. Among the monuments of the Shidertinskiy archaeological complex the special place is taken by the multilayered early man site of Shyderty 3, a mesolitas and eneolit eras. The monument is located in $7 \mathrm{~km}$ to the southwest from Shiderty's station on the left bank of the river of the same name. There are 6 cultural horizons with a general power of $130-150 \mathrm{~cm}$ investigated on the area of 840 sq.m are enclosed in deposits of a late Pleistocene and the Holocene. The complexes of archaeological subjects revealed on the early man site aren't always genetically connected among themselves. Therefore, this site was periodically visited by the carriers of various cultures leaving here the products: the autochthonic, i.e. carrying-on local traditions of cultural development. Happened here and the other groups with the cultural and technological traditions and methods of processing of a stone coming here to a certain season.

The monument has great cultural and historical and scientific value for studying of material and spiritual culture of ancient tribes of Saryarka of an era of mesolitas and eneolit.

Kurgan group Karasor 2. The Kurgan group Karasor 2 is located 2 $\mathrm{km}$ to the southwest from station Karasor, from South side from the highway Pavlodar - Ekibastuz, opposite to a milepost $93 \mathrm{~km}$. Consists of 2 stone and earth barrows with a diameter of $12 \mathrm{~m}$ and $0,7 \mathrm{~m}$ high - a barrow 1; a barrow of $2-14 \mathrm{~m}$ in the diameter and $1 \mathrm{~m}$ high. Represents typical funeral constructions of nomads of the early Iron Age. It has the scientific, cultural and historical significance as a source of material and spiritual culture of the nomadic tribes of Northeast Saryarka. The statue is near a highway, makes it convenient to visit it, which will give an overview of the monuments of this type, and can attract tourists and passing, but on condition of its museumification (Zhakupov and Atasoy 2014).

\section{CONCLUSIONS}

The Pavlodar region possesses unique and invaluable the "gifts of the nature" which are in great need in their safety for future generations. The main concentration of monuments of archeology of area coincides with the most perspective territories of development of tourism. The tourist branch still poorly develops in this region and has unorganized character. The provided description of some monuments of the Bayanaul and Ekibastuz areas presenting two main directions of archaeological and scientific tourism to areas is higher showed their huge potential.

The analysis of historical and cultural resources of area allows to draw the following conclusions: 
a) Museum traditions have to work for formation of tourist image of the region, to become business cards of cultural tourism;

b) The museums have advantage before other welfare objects (recreational opportunities of the museum can be used all the year round, there are no seasonal fluctuations);

c) The museums as socio cultural institutes (it is not only for storing, studying and showing), but also first of all are platforms for communication on distribution, promoting of knowledge for those who needs it;

d) The museums, having exclusive opportunities, have to put local history work in all aspects of geographical, archaeological, historical, literary, graphic, folklore study of local lore. The correct form of work and consistency will allow the museums to become influential objects of visit.

World practice indicates that archaeological tours are not widespread. Therefore, the routes to the archaeological sites vary in accordance with the needs of the customer, in this regard, tour operators, taking into account road and transport infrastructure can generate tourism product, based on the objects described in the archaeological parts.

\section{REFERENCES}

Akhmetov D. and Nurpeisov K. (2003), Irtysh and Pavlodar region., 80 p. Artykbaev Zh.O. and dr. Bayanaula (2001), Astana "Folio" printing house, $238 \mathrm{p}$.

Aryn E. M, Nuhuly A., Kudabayev A., Insebaev T.A et al. (2003a), The history of Pavlodar region in diagrams and tables. Pavlodar.

Aryn E. M, Nuhuly A., Kudabayev A., Insebaev T.A et al. (2003b), Series Kerekou-Bayan. Ruhnama. Pavlodar: SPC "Eco".

Yensebayev T.A. (2001), Essays on the history of Pavlodar region, Part I.II.

Zhakupov A. A. (2014), The need for the development of ecotourism in Bayanaul National Nature Park. Materials of Republican scientifictheoretical conference. "XI Seyfullinskiu read -11", - Astana,. 108$116 \mathrm{pp}$.

Zhakupov A. and Atasoy E. (2014), Geographical aspects of regional development of the city of Pavlodar. International Journal Sustainable Development. Bulgaria. Number 19, July 2014. 